\title{
Media Miniatur Rumah Adat Dengan Panel Surya untuk Meningkatkan Hasil Belajar Siswa Sekolah Dasar
}

\author{
Imawati $^{1 *}$, Retno Danu Rusmawat ${ }^{2}$, Nunung Nurjati ${ }^{3}$ (D) \\ 1,2,3 Pascasarjana Teknologi Pendidikan Universitas PGRI Adi Buana Surabaya \\ *Corresponding author: imawatics.ok87@gmail.com,retno.danu@unipasby.ac.id,noengcy@yahoo.com
}

\begin{abstract}
Abstrak
Rendahnya hasil belajar kognitif peserta didik dikarenakan proses pembelajaran yang dilakukan masih berpusat pada pendidik, sehingga pendidik lebih banyak mendominasi kegiatan belajar mengajar. Tujuan penelitian ini untuk mengembangkan media miniatur Miniatur Rumah Adat dengan Panel Surya untuk siswa kelas IV. Model pengembangan yang digunakan dalam penelitian ini adalah model ADDIE yang terdiri dari lima yang meliputi analisis, perencanaan pengembangan, penerapan, dan evaluasi. Subjek penelitian yang digunakan yaitu uji coba kelompok kecil 5 orang siswa, uji coba terbatas yang melibatkan siswa berjumlah 15 orang serta uji coba kelompok besar yang melibatkan siswa dengan jumlah 30 orang. Pengumpulan data dilakukan dengan menggunakan metode kuesioner, observasi dan wawancara. Teknik analisis data yang digunakan menggunakan analisis data kualitatif dan kuantitatif. Hasil penelitian menunjukkan validasi ahli materi oleh mendapatkan hasil prosentase $100 \%$. Uji coba ahli media mendapatkan hasil 88\%, dan Uji dari teman sejawat yang dilakukan oleh didapat prosentase $86 \%$. Uji coba kelompok besar didapat hasil total prosentase 88,7\%. Hal ini menunjukkan bahwa media miniatur rumah adat dengan panel surya untuk meningkatkan hasil belajar siswa kelas IV SD layak digunakan pada proses pembelajaran.
\end{abstract}

Kata kunci: Miniatur, Panel Surya, Hasil Belajar

\section{Abstract}

The low cognitive learning outcomes of students is due to the fact that the learning process is still teacher-centred, so that educators dominate more teaching and learning activities. The purpose of this research is to develop miniature media of traditional houses with solar panels for fourth grade students. The development model used in this study is the ADDIE model which consists of five which includes analysis, development planning, implementation, and evaluation. The research subjects used were small group trials of 5 students, limited trials involving 15 students and large group trials involving 30 students. Data was collected using questionnaire, observation and interview methods. The data analysis technique used is qualitative and quantitative data analysis. The results showed that the validation of material experts by getting a percentage of $100 \%$ results. The media expert trial got $88 \%$ results, and the peer test conducted by obtained a percentage of $86 \%$. Large group trials obtained a total percentage of $88.7 \%$. This shows that the miniature traditional house media with solar panels to improve the learning outcomes of fourth grade elementary school students is feasible to use in the learning process.

Keywords: Miniature, Solar Panels, Learning Outcomes.

\begin{tabular}{ll}
\hline History: & Publisher: Undiksha Press \\
Received : 05 Mei 2021 & Licensed: This work is licensed under \\
Revised : 12 Mei 2021 & a Creative Commons Attribution 4.0 License \\
Accepted : 20 Juni 2021 & Published : 25 Juli 2021
\end{tabular}

\section{Pendahuluan}

Pengembangan kurikulum 2013 merupakan langkah lanjutan pengembangan kurikulum berbasis kompetensi yang telah dirintis pada tahun 2004 dan KTSP 2006 yang mencakup kompetensi sikap, pengetahuan, dan keterampilan secara terpadu (Febriyanti, 2013; Novika Auliyana et al., 2018). Pembelajaran pada kurikulum 2013 yaitu tematik yang artinya pembelajaran yang dilakukan melalui berbagai tema sebagai pemersatu, sebagai pusat perhatian yang dipergunakan untuk memahami gejala dan konsep. Agama, Bahasa Indonesia, Matematika, IPA, IPS, PPKn, seni Budaya dan Parakarya, dan Penjas Orkes sudah terintegrasi ke dalam tema sehinggga sudah tidak ada lagi mata pelajaran (Amalia et al., 
2018; Muskania et al., 2019; Setiawan, 2020). Kurikulum 2013 dalam hasil belajar mencakup tiga ranah yaitu, pertama ranah kognitif merupakan kemampuan berpikir seseorang dalam memecahkan suatu masalah, kedua ranah afektif merupakan berhubungan dengan minat, perhatian, sikap, emosi, penghargaan, proses, internalisasi, dan pembentukan karakteristik seseorang, ketiga ranah psikomotorik merupakan kemampuan gerak yang dipengaruhi kematangan psikologis untuk menciptakan suatu kreasi (Jumriani et al., 2021; Mega et al., 2015). Hasil belajar yaitu sejumlah pengalaman wujud tindak lanjut yang diperoleh peserta didik dari proses pembelajaran (Novika Auliyana et al., 2018; Sinambela, 2013).

Kenyataannya, rendahnya hasil belajar kognitif peserta didik dikarenakan proses pembelajaran yang dilakukan kebanyakan masih berpusat pada pendidik, sehingga pendidik lebih banyak mendominasi kegiatan belajar mengajar (Izati et al., 2018; Prabowo, 2019). Disisi lain, proses pembelajaran lebih sering menggunakan metode pembelajaran konvensional (Astuti et al., 2013) Metode pembelajaran konvensional dapat menyebabkan rendahnya hasil belajar siswa dan memiliki dampak negatif yang lain (Halawa et al., 2020; Yanti \& Dwirandra, 2019). Selain itu, proses pembelajaran yang berlangsung secara monoton dapat membuat peserta didik menjadi bosan dan pasif. Tidak adanya kreatifitas dan siswa lebih pasrah dengan apa yang diberikan gurunya. Berdasarkan hasil observasi di SD AL FALAH DARUSSALAM kelas IV, menunjukkan bahwa hasil belajar kognitif masih sangat rendah. Hal tersebut terlihat pada saat guru menjelaskan pelajaran tematik, tampak siswa di kelas on line zoom pasif dan tidak semangat dalam mengikuti pelajaran. Penulis ingin membuat sebuah media pembelajaran yang menarik, unik, dan modern. Karena semua serba berteknologi maka media kami kombinasi dengan bentuk media fisik 3D . Masa Belajar Dari Rumah (BDR) mau tidak mau memaksa kita sebagai tenaga pendidik untuk menciptakan media yang modern dan harus menyesuaikan perkembangan zaman. Jika permasalahan tersebut dibiarkan akan memberikan dampak pada kualitas pendidikan.

Solusi yang dapat diberikan yaitu dengan menggunakan media pembelajaran pada proses pembelajaran. media pembelajaran merupakan semua sumber yang dibutuhkan dalam berkomunikasi dengan siswa (Gama et al., 2016; Pradeta \& Novi Catur Muspita, 2021). Penggunaan dan pemilihan media dalam pembelajaran harus mempertimbangkan seberapa besar tingkat interaksi yang dihasilkan, seberapa besar tingkat motivasi yang dihasilkan dan biaya yang dibutuhkan (Puspitorini et al., 2014; Susmiati, 2020). Dalam penggunaan media juga memperhatikan karakteristik peserta didik. Artinya semakin mendekati perbedaan karakteristik siswa dalam memilih media maka akan semakin tinggi pula tingkat motivasi yang akan dihasilkan oleh media tersebut. Media pembelajaran efektif digunakan apabila sesuai dengan karakteristik peserta didik dan sesuai dengan tuntutan materi (Amalia et al., 2018; Ilmawan Mustaqim, 2017). Media online yang digunakan untuk mengakses informasi dari sumber juga digunakan untuk berkomunikasi dengan peserta didik dan peserta didik lainnya (Khamparia \& Pandey, 2017; Pakpahan \& Fitriani, 2020).

Temuan penelitian sebelumnya menyatakan media sangat berperan penting dalam proses pembelajaran(Pradeta \& Novi Catur Muspita, 2021; Sulfemi, 2019). Media Miniatur Rumah Adat dengan Panel Surya merupakan media pembelajaran berupa miniatur rumah adat. Media pembelajaran Miniatur Rumah Adat dengan Panel Surya dapat digunakan untuk pembelajaran mencakup lima mata pelajaran yaitu: PPkn, Bahasa Indonesia, SBdP, IPA, dan IPS. Dengan menggunakan bahan yang aman diharapkan media pembelajaran dapat digunakan dalam waktu jangka panjang. Media pembelajaran Miniatur Rumah Adat dengan Panel Surya juga didesain dengan menarik sehingga siswa diharapkan dapat mengikuti proses belajar dengan baik. Media Miniatur Rumah Adat dengan Panel Surya yang merupakan miniatur Rumah Adat dibuat dengan desain yang menarik dengan dibuat semirip mungkin dengan bentuk aslinya dan ukurannya yang dapat terlihat jelas di dalam kelas. Ukuran dari miniatur Rumah Adat yaitu lebar $30 \mathrm{~cm}$, panjang $45 \mathrm{~cm}$, dan tinggi $30 \mathrm{~cm}$. Media ini akan 
dibuat dengan bahan utama kardus bekas. Yang bertujuan untuk mendaur ulang sampah agar lebih bernilai. Dalam pembuatan sebuah media pembelajaran tentu diharapkan adanya manfaat dalam keberlangsungan proses belajar mengajar. Begitu pula dengan dibuatnya media pembelajaran Miniatur Rumah Adat dengan Panel Surya yang diharapkan memberikan manfaat bagi keberlangsungan proses belajar mengajar. Tujuan penelitian ini mengembangkan media Miniatur Rumah Adat dengan Panel Surya dapat meningkatkan hasil belajar siswa kelas 4, pada pelajaran tematik di SD AL Falah Darussalam Sidoarjo. Media Miniatur Rumah Adat dengan Panel Surya dibuat semenarik mungkin, menjadi media yang berkesan dan menjadi pengalaman bermakna bagi siswa. Sehingga hasil belajar tercapai sesuai dengan tujuan pembelajaran.

\section{Metode}

Jenis Penelitian yang akan digunakan adalah pengembangan atau Research and Development (R\&D). Jenis dari penelitian ini ialah untuk membuat produk yang kemudian produk itu diuji kelayakannya. Pada penelitian pengembangan ini jenis produk yang dikembangkan adalah media "Miniatur Rumah Adat dengan Panel Surya". Model pengembangan yang digunakan dalam penelitian ini adalah model ADDIE yang terdiri dari lima tahapan menurut Tegeh, dkk (2014:42) yang meliputi (1) Tahap analisis (analysis), (2) Tahap perencanaan (design), (3) Tahap pengembangan (development), (4) Tahap penerapan (implemention), dan (5) Tahap evaluasi (evaluation). Penggunaan model ADDIE merupakan salah satu model desain pembelajaran yang sistematis. Pada setiap tahapan pengembangan model ADDIE ini terdapat kegiatan evaluasi terhadap aktivitas pengembangan disetiap tahapan, sehingga dapat meminimalisir tingkat kesalahan ataupun kekurangan dalam pengembangan produk media pembelajaran sampai pada tahap akhir.

Subjek penelitian yang digunakan yaitu uji coba kelompok kecil 5 orang siswa, uji coba terbatas yang melibatkan siswa berjumlah 15 orang serta uji coba kelompok besar yang melibatkan siswa dengan jumlah 30 orang. Namun intrumen yang dibuat akan diuji validitas dan reliabilitanya, agar instrument yang akan dipergunakan dapat dikatakan valid dan reliable. Hasil dari uji validitas yang menggunakan korelasi product moment akan dibandingkan dengan rtabel $\mathrm{N}=55$ pada tabel dengan $\alpha=0,05$ diperoleh nilai sebesar 0.266 . dengan demikian instrument telah teruji kevalidannya. Sedangkan untuk uji reliabilitas instrument pengujian reliabilitas menunjukkan bahwa nilai koefisien reliabilitas variabel yang digunakan, dalam variabel di atas lebih besar dari nilai r-tabel sebesar 0.6. maka hasil jawaban responden dapat diandalkan dengan kata lain bahwa apabila dilakukan penelitian yang sama dalam waktu yang berbeda maka responden akan memberikan jawaban yang sama, sehingga instrument yang dibuat dikatakan reliable.

Jenis data yang digunakan pada penelitian ini adalah kualitatif. Pada data kualitatif akan diperoleh data berupa saran, kritik, tanggapan dan masukan dari dosen ahli media pembelajaran, dosen ahli materi, guru kelas, dan siswa dengan mengisi kolom kritik dan saran pada angket. Pada data kuantitatif penilaian dari dosen ahli media pembelajaran, dosen ahli materi, guru kelas, dan siswa dengan mengisi kolompenilaian pada saat uji coba produk. Teknik analisis dan interpretasi data yang dipergunakan adalah skor angket validasi dan angket siswa. Skor angket berupa penilaian yang diberikan ahli materi, ahli media dan ahli desain. Data yang diperoleh berdasarkan presentase akan dolah menjadi analisis kualitatif data yang muncul berwujud kata-kata dan bukan rangakaian angka dalam Miles-Huberman (2009:15-16). Metode analisis deskriptif prosentase. 


\section{Hasil dan Pembahasan Hasil Penelitian}

Berdasarkan hasil analisis pengembangan media miniatur rumah adat dengan panel surya untuk meningkatkan hasil belajar siswa kelas IV SD menggunakan pengembangan model ADDIE yang terdiri dari lima tahapan menurut Tegeh, dkk (2014:42) yang meliputi (1) Tahap analisis (analysis), (2) Tahap perencanaan (design), (3) Tahap pengembangan (development), (4) Tahap penerapan (implemention), dan (5) Tahap evaluasi (evaluation). Pada tahap pertama yaitu analisis. Tahap analisis ini bertujuan untuk mencari dan menentukan materi yang dipilih untuk dikembangkan dalam media Miniatur Rumah Adat dengan Panel Surya agar sesuai dengan materi tematik kelas 4. Berdasarkan hasil wawancara dan observasi kepada guru kelas IV di SD AL Falah Darussalam Sidoarjo, dan menemukan informasi bahwa peserta didik mengalami kendala dalam menerima pembelajran yang diberikan oleh guru, peserta didik juga cepat merasa bosan. Tahap kedua yaitu perencanaan, pada tahap ini dilakukan kegiatan desain gambar yang diperlukan dalam pembuatan media miniature rumah.

Ketiga tahap pengembangan, tahapan ini merupakan bentuk validasi tahap awal dan dapat disebut dengan metode trianggulasi yang melibatkan responde uji ahli atau pakar (ahli isi, ahli rancangan pembelajaran, atau ahli IT), Teman sejawat dan sasaran produk (dalam pendidikan dan pembelajaran adalah pebelajar). Setelah dilakukan validasi, hasil dinalisis dengan analisis deskriptif untuk mengetahui apakah produk tersebut dapat dipergunakan pada tahap berikutnya atau tidak. Dari pengembangan produk yang direncanakan uji validasi yang dilakukan mendapatkan hasil penilaian dan kelayakan cukup signifikan yaitu 91,4 \% dan saran yang diberikan adalah agar bentuk huruf dan ukuran font dapalam tampilan agar dibuar berbeda. Ini semua dilakukan peneliti untuk merevisinya. Selanjutnya validasi ahli materi juga mendapatkan hasil simpulan bahwa produk yang dikembangkan dapat diterapkan pada uji coba berikutnya. Pada validasi ahli materi oleh mendapatkan hasil prosentase $100 \%$.

Uji coba ahli media mendapatkan hasil $88 \%$, dan Uji dari teman sejawat yang dilakukan oleh didapat prosentase $86 \%$, ini juga menandakan bahwa produk yang dikembangkan layak untuk dapat dilaksanakan pada uji coba selanjutnya. Namun untuk validasi awal tentang tranggapan siswa tentang produk yang dikembangkan yang dilakukan pada 5 orang siswa pada aspek materi atau isi materi pembelajaran terdapat prosentasi $64 \%$ yaitu pada instrument nomor item 1dan nomor 2, item nomor 4 dan nomnor 6 mendapatkan $68 \%$, serta item nomor 3 pada aspek keenarikan mendapatkan kelayakan 68\%, sekalipun ini tidak membawa pengaruh terhadap pelasanaan uji coba pada kelompok terbatas karena prosentase total dalam penilaian mendapatkan $69,1 \%$, namun peneliti tetap melakukan revisi pada semua produk yang dikembangkan. Sehingga untuk menyempurnakan produk maka tetap dilakukan revisi terhadap produk.

Pada uji coba terbatas yang dilakukan pada siswa yang berjumlah 15 orang siswa telah mendapatkan tanggapan siswa pada aspek materi adanya kemajuan dari revisi produk yang dilakukan oleh peneliti dari prosentase $64 \%$ menjadi 78,6 \% pada item nomor 1 dan 2 . Demikian pula pada item nomor 4 dan dan 6 juga mengalami kenaikan respo siswa dari $68 \%$ menjadi $82,6 \%$. Sedangkan dari aspek kemenarikan dari itrem nomor 3 yang semula mendapakan hasil validasi sebesar $68 \%$ mendapatkan kenaikan menjadi $80 \%$. Ini menandakan bahwa produk dapat dilakukan dalam uji coba dalam kelompok besar. Dalam uji coba kelompok besar didapat hasil total prosentase 88,7 \%. Uji coba ini dilakuan dalam kelas besar yaitu pada kelas yang dijadikan sujek uji coba yang berjumlah 30 orang siswa. Kenaikan respon siswa terhadap pembelajaran tematik dengan pembuatan media miniature dapat diterima oleh siswa sebagai bahan pengembangan bahan ajar dalan proses pembelajaran. hal tersebut menunjukkan bahwa media miniatur rumah adat dengan panel 
surya untuk meningkatkan hasil belajar siswa kelas IV SD layak digunakan pada proses pembelajaran.

\section{Pembahasan Hasil Penelitian}

Berdasarkan hasil analisis data yang telah dilakukan maka media miniatur rumah adat dengan panel surya untuk meningkatkan hasil belajar siswa kelas IV SD mendapat kualifikasi baik, sehingga layak digunakan pada proses pembelajaran. Media miniatur rumah adat dengan panel surya wajib dikembangkan karena media ini dapat membantu siswa selama proses pembelajaran dan menarik minat siswa sehingga dapat meningkatkan hasil belajar siswa kelas IV SD. Media ini layak digunakan dilihat dari beberapa aspek. Pertama dari segi penyajian materi sesuai dengan tuntutan pembelajaran tematik. Pembelajaran yang terintegrasi ke dalam tema atau tematik merupakan suatu model pembelajaran dengan pendekatan saintifik yang membuat keterlibatan peserta didik secara aktif dan menyenangkan yang tidak semata-mata peserta didik untuk mengetahui melainkan juga learning to do, learning to be, dan learning to live together(Mulyadin, 2016; Rakhmayanti \& Subagio, 2019). Pembelajaran tematik itu tidak hanya menyatukan beberapa mata pelajaran tetapi juga melibatkan peserta didik untuk ikut aktif dalam proses pelaksanaan

Kedua, media miniatur rumah adat dengan panel surya mendapatkan kualifikasi sangat baik dan layak diterapkan disebabkan karena media yang dikembangkan memudahkan siswa dalam memahami materi pelajaran. Pada aspek desain, kejelasan gambar, kesesuaian pemilihan warna, kesesuaian bentuk dan penggunaan contoh rumah adat yang konkret sangat baik sehingga memudahkan siswa dalam memahami materi. Selain itu materi yang disajikan dalam media pembelajaran ini sesuai dengan kompetensi dan tujuan pembelajaran serta sesuai dengan karakteristik siswa kelas I. Media Miniatur Rumah Adat dengan Panel Surya merupakan media pembelajaran berupa miniatur rumah adat. Media pembelajaran Miniatur Rumah Adat dengan Panel Surya dapat digunakan untuk pembelajaran mencakup lima mata pelajaran yaitu: PPkn, Bahasa Indonesia, SBdP, IPA, dan IPS. Media pembelajaran adalah segala sesuatu yang digunakan untuk menyalurkan informasi sehingga dapat menarik minat belajar siswa (Diah Purwati et al., 2019).

Media ini menggunakan bahan yang aman diharapkan media pembelajaran dapat digunakan dalam waktu jangka panjang. Media pembelajaran Miniatur Rumah Adat dengan Panel Surya juga didesain dengan menarik sehingga siswa diharapkan dapat mengikuti proses belajar dengan baik. Media Miniatur Rumah Adat dengan Panel Surya yang merupakan miniatur Rumah Adat dibuat dengan desain yang menarik dengan dibuat semirip mungkin dengan bentuk aslinya dan ukurannya yang dapat terlihat jelas di dalam kelas. Ukuran dari miniatur Rumah Adat yaitu lebar $30 \mathrm{~cm}$, panjang $45 \mathrm{~cm}$, dan tinggi $30 \mathrm{~cm}$. Media ini akan dibuat dengan bahan utama kardus bekas. Yang bertujuan untuk mendaur ulang sampah agar lebih bernilai. Dalam pembuatan sebuah media pembelajaran tentu diharapkan adanya manfaat dalam keberlangsungan proses belajar mengajar. Begitu pula dengan dibuatnya media pembelajaran Miniatur Rumah Adat dengan Panel Surya yang diharapkan memberikan manfaat bagi keberlangsungan proses belajar mengajar.

Temuan penelitian sebelumnya menyatakan media miniatur dapat membantu siswa dalam memahami materi (Pradeta \& Novi Catur Muspita, 2021; Sulfemi, 2019). Produk yang dikembangkan dapat diprodyksi secara besar dan disebarkan kepada siswa dan guru yang memiliki mata pelaaran yang sama. Selain itu disebarkan kepada sekolah lain yang setingkat untuk memfungsikan materi pengembangan ini. Dengan dibuatnya media pembelajaran miniatur rumah adat dengan panel surya, ini peneliti berharap para peserta didik lebih berminat pada materi ini dan hasil belajar pun akan lebih meningkat. 


\section{Simpulan}

Pembelajaran tematik dengan media miniature rumah adat dengan panel surya untuk tema 2 selalu berhemat energy untuk meningkatkan hasil belajar siswa kelas IV Sekolah Dasar Al-Falah Darussalam, Waru Sidoarjo secara signifikan mendapat kualifikasi baik. Oleh karena itu produk media minuarut berbasis pembelajaran tematik dapat disosialisasi dan didesiminasi untuk dicetak sebagai pedoman dalam mengajar di kelas IV sekolahg dasar, sehingga dapat disebarkan kepada guru-guru dan siswa sekolah tempat penelitian dilakukan maupun di sekolah dasar lainnya yang memiliki pelajaran yang sama. Implikasi penelitian ini diharapkan dapat meningkatkan hasil belajar siswa.

\section{Daftar Rujukan}

Amalia, M. D., Agustini, F., \& Sulianto, J. (2018). Pengembangan Media Diorama Pada Pembelajaran Tematik Terintegrasi Tema Indahnya Negeriku Untuk Meningkatkan

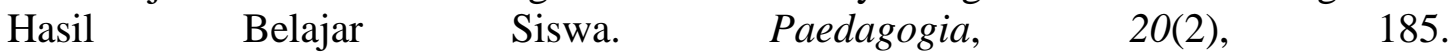
https://doi.org/10.20961/paedagogia.v20i2.9850.

Astuti, N. P. A. W., Ardana, I. K., \& Suardika, I. W. R. (2013). Pengaruh Model Pembelajaran Savi Bermuatan Mind Mapping Terhadap Hasil Belajar IPA Siswa Kelas Iv Sekolah Dasar Gugus III Mengwi. Mimbar PGSD Undiksha, 1(1). https://doi.org/http://dx.doi.org/10.23887/jjpgsd.v1i1.1231.

Diah Purwati, N. L. P., Wibawa, I. M. C., \& Margunayasa, I. G. (2019). Pengaruh Numbered Head Together Berbantuan Gambar Terhadap Penguasaan Kompetensi Pengetahuan IPA. Jurnal Pedagogi Dan Pembelajaran, 2(3), 282. https://doi.org/10.23887/jp2.v2i3.19275.

Febriyanti. (2013). Kurikulum Pendidikan Tinggi Di Era Globalisasi (Pergeseran Dari Kurikulum Inti Dan Institusional Ke Kurikulum Berbasis Kompetensi). Ta'di Jurnal Pendidikan Islam, 18(2). https://doi.org/https://doi.org/10.19109/tjie.v18i02.51.

Gama, I. G. B. S., Mahadewi, L. P. P., \& Jampel, I. N. (2016). Pengembangan Multimedia Tutorial Interaktif Sumber Daya Alam dan Teknologi pada Mata Pelajaran IPA Kelas IV di SDN 3 Banyuasri. Jurnal EDUTECH, 6(3), 1-10. https://doi.org/10.23887/jeu.v4i3.8560.

Halawa, N., Ramadhan, S., \& Gani, E. (2020). Kontribusi Minat Baca Terhadap Kemampuan Membaca Pemahaman Siswa. Jurnal Edukasi Khatulistiwa, 3(1), 27. https://doi.org/10.26418/ekha.v2i2.32786.

Ilmawan Mustaqim, N. K. (2017). Pengembangan Media Pembelajaran Berbasis Augmented Reality. Jurnal Edukasi Elektro, 1(1), 36-48. https://doi.org/10.24252/lp.2018v21n1i6.

Izati, Wahyudi, \& Sugiyarti, M. (2018). Project Based Learning Berbasis Literasi untuk Meningkatkan Hasil Belajar Tematik. Jurnal Pendidikan, 3(9), 1122-1127. https://doi.org/http://dx.doi.org/10.17977/jptpp.v3i9.11508.

Jumriani, Syaharuddin, Hadi, N. T. F. W., Mutiani, \& Abbas, E. W. (2021). Telaah Literatur ; Komponen Kurikulum IPS Di Sekolah Dasar pada Kurikulum 2013. Jurnal Basicedu, 5(4), 2027-2035. https://doi.org/10.31004/basicedu.v5i4.1111.

Khamparia, A., \& Pandey, B. (2017). Impact of interactive multimedia in E-learning technologies: Role of multimedia in E-learning. Enhancing Academic Research With Knowledge Management Principles, April, 199-227. https://doi.org/10.4018/978-15225-2489-2.ch007.

Mega, C., Pudjawan, K., \& Margunayasa, I. G. (2015). Analisis sikap sosial siswa kelas V pada pembelajaran dengan kurikulum 2013. Mimbar PGSD Universitas Pendidikan Ganesha, 3(1). https://doi.org/http://dx.doi.org/10.23887/jjpgsd.v3i1.5631. 
Mulyadin. (2016). Mulyadin. (2016). Implementasi Kebijakan Pembelajaran Tematik Terpadu Kurikulum 2013 Di SDN Kauman 1 Malang Dan Sd Muhammadiyah 1 Malang. Jurnal Pendidikan Edutama, 3(2), $31 \quad-\quad 48$. https://doi.org/10.30734/jpe.v3i2.35.

Muskania, R. T., Badariah, S., \& Mansur, M. (2019). Pembelajaran Tematik Menggunakan Media Video Scribe Pada Siswa Kelas IV Sekolah Dasar. Elementary: Islamic Teacher Journal, 7(1). https://doi.org/10.21043/elementary.v7i1.4927.

Novika Auliyana, S., Akbar, S., \& Yuniastuti. (2018). Penerapan Pembelajaran Tematik Terpadu di Sekolah Dasar. Jurnal Pendidikan: Teori, Penelitian, Dan Pengembangan, 3(12), 1572-1582. https://doi.org/10.17977/jptpp.v3i12.11796.

Pakpahan, R., \& Fitriani, Y. (2020). Analisa Pemafaatan Teknologi Informasi Dalam Pemeblajaran Jarak Jauh Di Tengah Pandemi Virus Corona Covid-19. JISAMAR (Journal of Information System, Applied, Management, Accounting and Researh), 4(2), 30-36. http://journal.stmikjayakarta.ac.id/index.php/jisamar/article/view/181.

Prabowo, D. M. (2019). Pegembangan Media Diorama 3 Dimensi Dalam Pembelajaran Ipa Materi Ekosistem Kelas V. Joyful Learning Journal, 6(4), 234-242. https://doi.org/10.15294/jlj.v6i4.17008.

Pradeta, F. D., \& Novi Catur Muspita. (2021). Pengembangan Model Pembelajaran Sejarah Wisata Negeri Dongeng Berbasis Taman Miniatur Melalui Pendekatan Outdoor Study di SMA Negeri Ponggok Blita. Jurnal Kajian Komunikasi Dan Studi Media, 10(1), 54-62. https://doi.org/10.35457/translitera.v10i1.1425.

Puspitorini, Subali, \& Jumadi. (2014). Penggunaan Media Komik Dalam Pembelajaran IPA Untuk Meningkatkan Motivasi Dan Hasil Belajar Kognitif Dan Afektif. Cakrawala Pendidikan, 33(3), 413-420.

Rakhmayanti, E., \& Subagio, M. (2019). Efektivitas Penggunaan Media Monopoli Tematik Terhadap Aktivitas Dan Hasil Belajar Kognitif Siswa Kelas Iv Di Sd Negeri Sumput Sidoarjo. Jurnal Penelitian Pendidikan Guru Sekolah Dasar, 7(3), 2975-2984.

Setiawan, A. R. (2020). Pembelajaran Tematik Berorientasi Literasi Saintifik. Jurnal Basicedu, 3(2), 524-532. https://doi.org/https://doi.org/10.31004/basicedu.v4i1.298.

Sinambela, P. nauli josip mario. (2013). Kurikulum 2013 , Guru , Siswa , Afektif , Psikomotorik , Kognitif. E-Journal Universitas Negeri Medan, 6(2), 17-29. https://jurnal.unimed.ac.id/2012/index.php/gk/article/view/7085/6067.

Sulfemi, W. B. (2019). Model Pembelajaran Contextual Teaching And Learning (CTL) Berbantu Media Miniatur Lingkungan Untuk Meningkatkan Hasil Belajar IPS. $\begin{array}{lllll}\text { Edunomic Jurnal Pendidikan } & 73 .\end{array}$ https://doi.org/10.33603/ejpe.v7i2.1970.

Susmiati, E. (2020). Meningkatkan Motivasi Belajar Bahasa Indonesia Melalui Penerapan Model Discovery Learning dan Media Video Dalam Kondisi Pandemi Covid-19 bagi Siswa SMPN 2 Gangga. Jurnal Penelitian Dan Pengembangan Pendidikan, 7(3), 210-215. https://doi.org/10.33394/jp.v7i3.2732.

Yanti, N. M. Y. W. A., \& Dwirandra, A. A. N. B. (2019). The effect of profitability in income smoothing practice with good corporate governance and dividend of payout ratio as a moderation variable. International Research Journal of Management, IT and Social Sciences, 6(2), 12-21. https://doi.org/10.21744/irjmis.v6n2.601. 